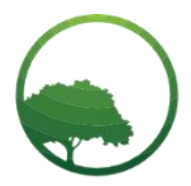

Research in Business \& Social Science

IJRBS VOL 10 NO 3 ISSN: 2147-4478

\title{
Examining the effect of firm-specific factors on the automotive industry in Indonesia
}

\author{
(D) Reschiwati (iD) Alya Budiantini, (D) Gusmiarni \\ (a) Chairperson, Sekolah Tinggi Ilmu Ekonomi Y.A.I, Jalan Salemba Raya No 7-9 A, Paseban, 10440, Jakarta, Indonesia \\ ${ }^{(b, c)}$ Sekolah Tinggi Ilmu Ekonomi Y.A.I, Jalan Salemba Raya No 7-9 A, Paseban, 10440, Jakarta, Indonesia
}

\author{
A R T I CLE IN F O \\ Article history: \\ Received 04 March 2021 \\ Received in rev. form 14 April 2021 \\ Accepted 16 April 2021 \\ Keywords: \\ Firm Value, Firm Size, Liquidity, \\ Profitability, Solvency \\ JEL Classification: \\ G32
}

\begin{abstract}
A B S T R A C T
This study aims to examine the factors that affect the value of manufacturing companies in the Automotive Industry Sub-Sector Listed on the Indonesia Stock Exchange in 2015 - 2019. These factors are firm size and financial performance. Financial performance consists of liquidity, profitability and solvency. The number of manufacturing companies in the Automative Industry sub-sector which was made into the population was 13. Sampling was using purposive sampling technique. Based on the predetermined criteria, there were 10 companies that met the criteria so that there were 50 observations. Data collection techniques use documentation from financial reports published on the official website of the Indonesia Stock Exchange. The model used in this research is panel data regression using the Eviews application. The findings of this study indicate that of the four independent variables tested, only the solvency variable affects firm value, but simultaneously firm size and financial performance have a significant effect on firm value. The results of this study indicate that in general, stock investors view the importance of all financial ratios, but can ignore short-term financial symptoms that are reflected in company size, profitability, and liquidity, but should pay more attention to the security of long-term investments which can be seen in solvency.
\end{abstract}

() 2021 by the authors. Licensee SSBFNET, Istanbul, Turkey. This article is an open access article distributed under the terms and conditions of the Creative Commons Attribution (CC BY) license (http://creativecommons.org/licenses/by/4.0/).

\section{Introduction}

The development of the automotive world is currently growing rapidly, especially in Indonesia. The products launched are also increasingly sophisticated following technological developments in order to meet consumer satisfaction. Of course, these companies make a lot of efforts to keep up with technological developments. These efforts are inseparable from the costs or capital used for product development and promotion costs. Automotive companies are required to improve their performance in order to compete and earn profits. According to the Indonesian Ministry of Industry, the benefits obtained are one of the company's goals as a business institution, so that each company provides satisfactory performance because it produces efficiently so that it can continue to create competitiveness that has advantages (Kemenperin, 2018).

The automotive industry has bright and profitable prospects, because currently it is facing high competition and is always keeping abreast of fast technological developments. In addition, as the population and volume of vehicles in Indonesia increase, it will automatically increase the amount of demand for automotive products. Automotive products have also become a daily necessity for every individual or company. In this condition, automotive companies will take certain steps to meet the increasing demand for automotive products, namely by increasing production capacity, expanding companies, expanding distribution networks and other business ventures, all of which will have an impact on financial performance.

The company's financial performance can be measured in various ways, including by fundamental and technical analysis. Fundamental factors are factors related to the performance of the company itself. The indicators used in the analysis of company performance are liquidity, activity, profitability and solvency.

* Corresponding author. ORCID ID: 0000-0002-8801-6562

(C) 2021 by the authors. Hosting by SSBFNET. Peer review under responsibility of Center for Strategic Studies in Business and Finance. https://doi.org/10.20525/ijrbs.v10i3.1092 
For this reason, the assessment of the company is very important and beneficial, both for the company and for those outside the company with an interest in the company concerned. For a company, financial performance can be used as a measuring tool in assessing the success of the company, it can also be used as a consideration in making decisions and planning in the future. Meanwhile, outside the company can be used as a material for consideration in making investment decisions on the company concerned so that it will affect the value of the company.

Firm value is the investor's perception of the company's success rate in managing its resources at the end of the current year, which is reflected in the company's stock price. The higher the stock price, the higher the company value, on the contrary, the lower the stock price, the lower the company value or the company's performance is not good. For creditors, the value of the company is related to the liquidity of the company, that is, the company is assessed as being able or not to repay the loan provided by the creditor. If the implied company value is not good, investors will value the company low.

In the process of maximizing company value, it is not uncommon for company managers to have different goals and interests that are contrary to the main objectives of the company and often ignore the interests of shareholders. Different interests between managers and shareholders have resulted in a conflict which is commonly referred to as agency conflict. This happens because managers prioritize personal interests, on the other hand, shareholders do not like the personal interests of managers because what the manager does will increase costs for the company, causing a decrease in company profits and affecting stock prices, thereby reducing the value of the company (Permanasari, 2010).

To be able to carry out its operating activities, the company must be in a favorable condition. Without profit, it will be difficult for companies to attract outside capital. Companies that have a high level of profitability will be interested in their shares by investors. Thus, profitability can affect firm value.

The last factor affecting firm value is firm size. The size of the company is reflected in the total assets of a company, assets are a reflection of the income and assets owned by the company, the bigger the assets, the higher the value of the company. In addition, firm size is a consideration for obtaining capital in the capital market (Solikin, et al., 2015). The bigger the size of a company, the easier it is for the company to get sources of funding for the company's operations. The better and the more sources of funds that are obtained, the maximum support for the company's operations will be, thereby increasing the share price of the company (Pantow, et al., 2015).

Research conducted by (Cecilia \& Bahri Torong, 2015) concluded that firm size has a negative and insignificant effect on firm value, while profitability has a positive and significant effect on firm value.

This study was conducted to analyze the effect of company size and financial performance on firm value with the following problem formulations:

i. Is there an effect of liquidity on firm value in manufacturing companies with the automotive industry sub-sector listed on the IDX for the 2015-2019 period?

ii. Is there an effect of solvency on firm value in manufacturing companies with the automotive industry sub-sector listed on the IDX for the 2015-2019 period?

iii. Is there an effect of profitability on firm value in manufacturing companies with the automotive industry sub-sector listed on the IDX for the 2015-2019 period?

iv. Is there an effect of company size on firm value in manufacturing companies with the automotive industry sub-sector listed on the IDX for the 2015-2019 period?

\section{Literature Review}

\section{Theoretical and Conceptual Background}

Agency Theory

Agency theory explains the relationship between management as agents and owners of capital as principal. This theory was first put forward by (Jensen \& Meckling, 1976) which defines agency relationship as a contract between one or more principals who ask the agent to do some work related to their interests, including delegating decisions or giving authority to agents. The management as the manager of the company must be responsible to the owner of the capital because the owner of the capital has given authority to management to make the best decisions for the progress of the company they manage. Based on the basic assumption described by Eisenhardt (1989) in (Haryono, et al., 2017), the manager will act based on the opportunistic nature of humans and as an ordinary human being will be more concerned with himself than taking an action that can increase shareholder prosperity. The differences in interests that occur cause agency conflicts between management and shareholders. In addition, agency conflicts can also occur with minority and majority shareholders, as well as shareholders and creditors. 


\section{Signaling Theory}

Signaling theory is a theory put forward by (Ross, 1977). In this theory, it is argued that company executives will have better information and tend to provide this information to potential investors. The existence of information in the form of "good news" that the company has regarding future prospects is expected to increase the company's share price. Broadly speaking, the availability of information is closely related to signaling theory. Information is an important tool for business people and investors, through information it can be seen a picture of the current state of the company, the past, as well as the company's future prospects. Relevant, accurate, timely, and complete information is important that investors must have as an analytical tool in investment decisions in the capital market. Through the publication of information or information announced in the media, investors will later use it as a bad signal or a good signal in investment decision efforts. Market reaction when the announcement is received is expected when the announcement contains a good signal (Jogiyanto, 2000).

Stock trading volume will reflect market reaction. The company has good prospects in the future, if the information conveyed contains good signals. Thus investors will be interested in trading stocks. This is reflected in changes in share trading volume where the market reaction is positive. Market efficiency will show the relationship between published information related to information in the form of financial, political, environmental and social reports on fluctuations in the volume of stock trading (Cecilia \& Bahri Torong, 2015), the efficient capital market can be defined as a market where the price of the securities has described relevant information.

\section{Legitimacy Theory}

Legitimacy is a psychological condition of taking sides of people and groups of people who are very sensitive to the symptoms of the surrounding environment, both physical and non-physical (Hadi, 2011). (Deegan, 2002) describes that legitimacy can be obtained when there is a match between the existence of the company and does not interfere with or conform to the existence of a value system that exists in society and the environment. When there is a shift towards non-conformity, then the legitimacy of the company is threatened.

Nasi, Philips, and Zyglidopoulos in (Nurhayati, 2006) said that Legitimacy theory focuses on the adequacy of corporate social behavior. This means that society judges an organization based on the image that the company will create for the company itself. Furthermore, organizations can establish their legitimacy by combining company performance with public expectations or perceptions. When there is a gap between the expectations of the community and the company's social behavior, a legitimacy problem will arise (Nurhayati, 2006).

From the description above, it can be concluded that company legitimacy in the eyes of stakeholders is a significant factor in supporting the company's image and reputation in the eyes of stakeholders (Hadi, 2011). Thus, company value is a long-term investment and has benefits in increasing its image and legitimacy, so that it can be used as the basis for the company's strategy construction. The harmony between organizational actions and community values does not always work as expected. It is not uncommon for potential differences between organizations and social values that can threaten the legitimacy of the company and even lead to the closure of the company.

\section{Firm Value}

A company is an organization that combines and organizes various resources with the aim of producing goods and or services for sale (Hermuningsih, 2013). Firm value is the investor's perception of the company which is often associated with stock prices. High company value is the desire of company owners, because high values indicate that the prosperity of shareholders is also high (Hemastuti, 2014). The goal of company management is to maximize the value of the shareholders' wealth (Harmono, 2017). Firm value can be measured through the market share price value based on the formation of the company's stock price in the market, which is a reflection of the public's assessment of the company's real performance. It is said in real terms because the price formation in the market is a meeting of points of stability of the power of demand and points of stability of the power of supply of prices, which in real terms occur buying and selling of securities in the capital market between sellers (issuers) and investors, or often called equilibrium. market. Therefore, in the financial theory of the capital market, the market share price is referred to as the concept of firm value (Harmono, 2017). The higher the stock price, the higher the value of a company.

\section{Firm Size}

Firm size is a scale that can be classified based on the size of the company according to various ways, including: log total assets, log total sales, market capitalization. Basically according to (Herawaty. \& Suwito, 2005) company size is divided into 3 categories, namely large companies, medium companies and small companies. There are various proxies that are usually used to represent company size, namely number of employees, total assets, total sales, and market capitalization. Company scale is a measure used to reflect the size of the company based on the company's total assets (Herawaty \& Suwito, 2005). According to (Ghozali, 2006) the assessment of company size can use the measure of total assets. In this study, researchers used a proxy for total assets, this is intended to reduce excess data fluctuations. If the total asset value is directly used, the variable value will be very large, billions or even trillions. Since the company's total assets are of large value, this can be simplified by transforming it into a natural logarithm, without changing the proportion of the original original value. 


\section{Financial performance}

Financial performance is a description of the company's financial condition in a certain period, both regarding the aspects of raising funds and channeling funds, which are usually measured by indicators of capital adequacy, liquidity, and profitability (Jumingan, 2006). Performing financial ratio analysis is important in running a business. Financial ratios must be understood because there are many benefits that can be obtained from analyzing them. These financial ratios will help in measuring the success of the company. Financial ratios are a tool for analyzing and measuring company performance using the company's financial data. Financial data can be taken from financial reports such as income statements, balance sheets, cash flow reports, and other reports. Based on the objective, the financial ratios are divided into four. The financial ratios used for performance appraisal are: (1) Liquidity consisting of Current Ratio and Quick Ratio; (2) Profitability consists of Gross Profit Margin, Operating Profit Margin, Net Profit Margin; (3) Solvency consists of Debt to Total Assets Ratio and Debt to Equity Ratio.

\section{Conceptual Framework}

\section{Firm Size and Firm Value}

Firm size is a measure that describes the size of the company which can be assessed from the total asset value of the company. A large company size shows that the company is experiencing good growth. Companies with large growth will find it easier to enter the capital market because investors get a positive signal to companies that have large growth so that this positive response reflects the increase in company value (Prasetyorini, 2013).

This statement is supported by a signaling theory which states that the ups and downs of market prices will affect investors' decisions. And the above conjecture is corroborated by previous research conducted by (Prasetyorini, 2013), which states that the firm size variable has a positive and significant effect on firm value.

\section{Liquidity and Firm Value}

The assumed financial performance with the liquidity ratio illustrates the company's ability to meet its financial obligations which must be fulfilled immediately in the short term or one year from the date the balance sheet is made (Rahardjo, 2009). Liabilities or short-term debt in the balance sheet can be fulfilled or closed from current assets which also rotate in the short term.

The value of the company obtained from operating activities for several years is determined by public trust in the company. Increasing the value of a company is an achievement, because this means that the welfare of the company and its owners is also increasing. Meanwhile, the liquidity ratio that describes the company's financial performance in terms of liabilities can affect the public's judgment, especially investors, in order to give confidence to companies to invest. If the company still has a good ability to fulfill its short-term obligations (one year period) by using current assets, the company can be said to be liquid. Thus, investors do not need to worry about investing their funds, if something goes wrong. Based on the description above, it can be concluded that the higher the liquidity ratio of a company, the higher the company's liabilities that are borne by current assets, thus increasing public confidence, this means that the company's value is also getting better.

\section{Profitability and Firm Value}

Company profitability is the company's ability to generate net income from activities carried out in the accounting period. High profitability will give an indication of the company's good prospects so that it can trigger investors to participate in increasing demand for shares. The higher the company's profitability will also increase the company's earnings per share. An increase in earnings per share of the company will attract investors to invest by buying company shares. With so many investors buying company shares, it will increase the company's stock price so that it will increase the company's value (Prasetyorini, 2013). This statement is supported by a signaling theory which states that the ups and downs of market prices will affect investors' decisions. And the above allegations are corroborated by research conducted by (Pantow, et al., 2015), (Saputri Dewi, et al., 2014), (Thaib, 2017) and (Dj, et al., 2012) which state that profitability has significant positive effect on firm value.

\section{Solvency and Firm Value}

The solvency of the company shows the company's ability to meet its long-term obligations. This ratio is used to measure the company's ability to meet its long-term obligations. To carry out its operations, each company has various needs, especially those related to funds so that the company can run properly. Funds are always needed to cover all or part of the costs required, both shortterm funds and long-term funds. Funds are also needed for expansion or expansion of new businesses or investments.

In Taurisina's research (Firnanda \& Oetomo, 2016) on the analysis of liquidity, profitability, solvency, and inventory turnover on company value at retail companies listed on the Indonesia Stock Exchange for the period 2007-2014. The data collection technique used is the documentation technique, namely the method of data collection by researchers by looking at financial reports on the IDX in the 2007-2014 period. This study shows that solvency has a positive effect on firm value. A good solvency ratio will affect public confidence in a company, thereby increasing the value of the company. The lower the solvency ratio, the better the company value. So it can be concluded that solvency has an effect on firm value. 
The relationship model between variables for this study is described as follows:

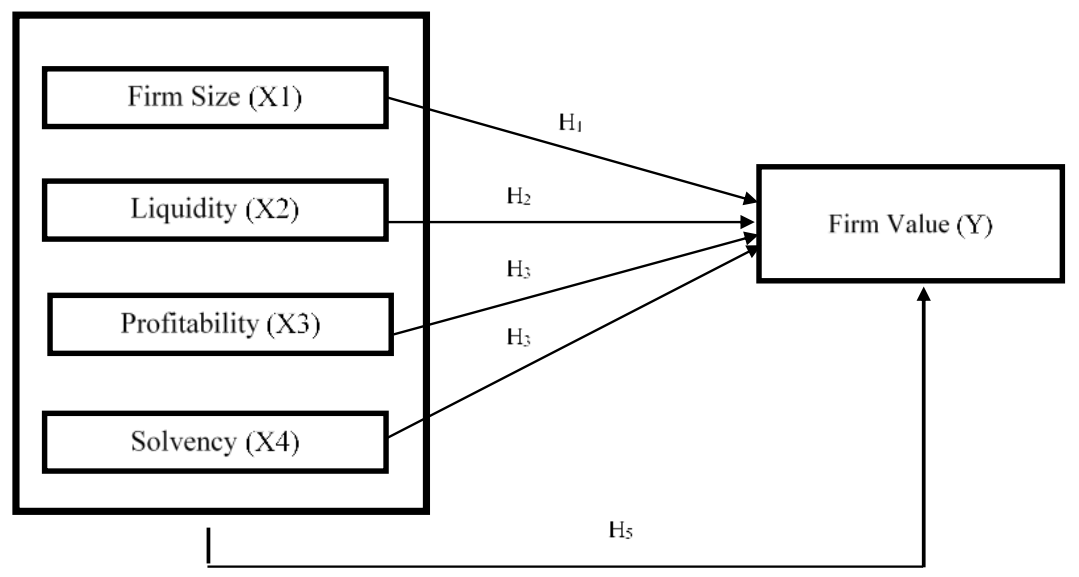

Figure 1: The Effect of Firm Size, Liquidity, Profitability and Solvency on Firm Value

Hypothesis

H1: Firm size has a positive and significant effect on firm value

$\mathrm{H} 2$ : Liquidity has a positive and significant effect on firm value

H3: Profitability has a positive and significant effect on firm value

H4: Solvency has a positive and significant effect on firm value

H5: Firm Size, Liquidity, Profitability and Solvency simultaneously have a significant effect on firm value.

\section{Research and Methodology}

\section{Population and Sample}

The population in this study were automotive sub-sector manufacturing companies listed on the Indonesia Stock Exchange for the 2015-2019 period with 13 companies. The sample selection technique is by using purposive sampling with the criteria (a) Companies listed on the Indonesia Stock Exchange are included in the automotive sub-sector company; (b) Companies that have submitted their financial reports for 5 (five) consecutive years, namely 2015-2019; (c) These companies have been listed on the Indonesia Stock Exchange which has complete financial data for 2015-2019; (d) The company has conducted an IPO at least 2012; (e) Did not experience delisting during 2015-2019. There are 10 companies that meet the criteria.

\section{Measurement of Research Variables}

\section{Firm Value (Y)}

Every company listed on the Indonesia Stock Exchange (IDX) wants the price to measure the value of the company used in this study is price to book value (PBV) with the following formula:

$\mathrm{PBV}=$ Total Equity/Total number of Outstanding Shares

\section{Firm Size (X1)}

Firm size is one of the factors that influence corporate earnings management. Large companies are paid more attention to by the public so that they are more careful in conducting financial reporting, so that the impact of these companies is to report their conditions more accurately (Nasution and Setiawan).

In this study, company size is measured from the natural logarithm value of the company's total assets listed in the financial statements.

$$
\text { SIZE = Logarithm of Natural Total Assets }
$$




\section{Liquidity (X2)}

Liquidity is measured using the Current Ratio (CR), which is how the company's ability to pay its obligations by comparing the assets owned by the company with the company's short-term debt. The formula used is:

$$
\text { Current ratio }=\frac{\text { Current assets }}{\text { Current liabilities }}
$$

Profitability (X3)

Profitability in this study is measured using Return On Assets (ROA), which is the level of net profit the company receives in carrying out its operations. The formula used to measure Return On Assets (ROA) is:

$$
\text { ROA }=\frac{\text { Net Profit }}{\text { Total Assets }} \text { X 100\% }
$$

Solvency $(X 4)$

Solvency is measured using the Debt to Asset Ratio (DAR), which is to compare how big the assets are, with the total amount of debt the company has. The formula used is:

$$
\text { DAR }=\frac{\text { Total Liabilities }}{\text { Total Assets }}
$$

\section{Panel Data Analysis Method}

Before conducting panel data regression testing, there are three approaches used in the panel data regression analysis method, the three models are common effect, fixed effect and random effect.

\section{Selection of Estimation Model}

The tests carried out to get the best approach in panel data regression analysis are (1) the F Restricted Test (Chow Test) namely testing to determine the Fixed Effect (FEM) $t$ or Common Effect (CEM) model which is more appropriate to use in estimating panel data. If the result is FEM then continue with; (2) The Housman test is a statistical test to determine whether FEM or random effect (REM) is more appropriate to use in panel data regression. If the result is REM, then continue with; (3) The Lagrange Multiplier (LM) test is a test to determine whether the REM or CEM model is more appropriate

\section{Classic assumption test}

The classical assumption tests used are (1) Multicollinearity test which aims to test whether in the regression model that is formed there is a high or perfect correlation between the independent variables; (2) Heteroscedasticity test which aims to test whether in the regression model that is formed there is an inequality of variants of the regression model residuals.

\section{Hypothesis testing}

Hypotheses were tested using (1) Multiple Regression Analysis. (2) Simultaneous Significance Test (F Statistical Test); (3) Individual Parameter Significance Test (t-test) and Coefficient of Determination.

\section{Result and Discussion}

The results of selecting the estimation model

Chow test

Table 1: Chow Test Results

\section{Redundant Fixed Effects Tests}

Equation: Untitled

\begin{tabular}{llll}
\hline Test cross-section fixed effects & & & \\
\hline Effects Test & Statistic & d.f. & Prob. \\
\hline Cross-section F & 73.738556 & $(9,36)$ & 0.0000 \\
\hline Cross-section Chi-square & 148.352850 & 9 & 0.0000 \\
\hline
\end{tabular}

Based on table 1, it shows that the probability value on the F-test is 0.0000 and the Chi-Square value is 0.0000 , both values are smaller than 0.05, so it can be concluded that the model follows the Fixed Effect Model (FEM). 


\section{Hausman Test}

Table 2: Hausman Test Results

\begin{tabular}{llll}
\hline Correlated Random Effects - Hausman Test & & \\
\hline Equation: Untitled & & & \\
\hline Test cross-section random effects & Chi-Sq. Statistic & Chi-Sq. d.f. & Prob. \\
\hline Test Summary & 25.704162 & 4 & 0.0000 \\
\hline Cross-section random & & \\
\hline
\end{tabular}

Based on table 2, it shows that the probability value at the Chi-Square value is 0,000 , this value is less than 0.05 , so it can be concluded that according to the Hausman test, the model follows the Fixed Effect Model (FEM).

Because the Chow test and the Hausman test produce FEM, the Langrange Multiplier test is no longer needed, and the data is processed using the FEM.

Heteroscedacity Test Results

Table 3: Heteroscedasticity Test Results

\begin{tabular}{llll}
\hline Heteroskedasticity Test: White & & & \\
\hline F-statistic & 8.618736 & Prob. F(14,35) & 0.0000 \\
\hline Obs*R-squared & 38.75771 & Prob. Chi-Square(14) & 0.0004 \\
\hline Scaled explained SS & 63.44751 & Prob. Chi-Square(14) & 0.0000 \\
\hline
\end{tabular}

Based on table 3, the results of the calculation of the heterocedastity test show that the Obs $* \mathrm{R}$-Squared value has a prob value. ChiSquare is 0.0004 , this means that there are symptoms of heteroscedasticity that occur. To improve the data variables, one of the ways to do heteroskesdasticity is logarithmic repair. The log results were tested with Eviews8 software by testing heteroskesdasticity, namely with the following results:

Table 4: Results of the Repair Heteroscedasticity Test with Logarithms Heteroskedasticity Test: White

\begin{tabular}{llll}
\hline Heteroskedasticity Test: White & & & 0.0141 \\
\hline F-statistic & 2.499164 & Prob. F(14,35) & 0.0346 \\
\hline Obs*R-squared & 24.99582 & Prob. Chi-Square(14) & 0.0004 \\
\hline Scaled explained SS & 38.71903 & Prob. Chi-Square(14) \\
\hline
\end{tabular}

In the white test, the hypothesis proposed is:

Ho: There is no heteroscedasticity

Ha: There is heteroscedasticity

Based on table 4, it can be seen that the value of Obs * R-squared has a Chi-square probability value of $p=0.0346$, where the $\mathrm{p}$ value is more than $(<) 0.05$, thus the alternative hypothesis $(\mathrm{Ha})$ of heteroscedasticity in the model is accepted. 


\section{Hypothesis Testing Results}

Table 5: Results of Multiple Regression Analysis

\begin{tabular}{lllll}
\hline Variable & Coefficient & Std. Error & t-Statistic & Prob. \\
\hline $\mathbf{C}$ & -0.196095 & 0.677351 & -0.289503 & 0.7735 \\
\hline $\mathbf{X 1}$ & -0.017479 & 0.032808 & -0.532766 & 0.5968 \\
\hline $\mathbf{X} 2$ & 0.026540 & 0.078665 & 0.337384 & 0.7374 \\
\hline $\mathbf{X 3}$ & -0.638836 & 1.389434 & -0.459782 & 0.6479 \\
\hline $\mathbf{X} 4$ & 3.114902 & 0.408956 & 7.616715 & 0.0000 \\
\hline R-squared & 0.690329 & Mean dependent & 1.013875 & \\
\hline Adjusted R-squared & 0.662803 & S.D. dependent var & 0.867607 & 1.752600 \\
\hline S.E. of regression & 0.503808 & Akaike & info & 1.561397 \\
\hline Sum squared resid & 11.42202 & Schwarz criterion & & 1.634208 \\
\hline Log likelihood & -34.03493 & Hannan-Quinn criter. & 0.943652 \\
\hline F-statistic & 25.07886 & Durbin-Watson stat & \\
\hline Prob(F-statistic) & 0.000000 & & & \\
\hline
\end{tabular}

Based on the results of multiple regression analysis, it shows that the probability value of Firm Size (X1) on Firm Value is $0.5968>$ 0.05 , this means that firm size is not significant to firm value.If company size increases, the Firm Value will decrease and this will affect investors. According to Ghozali (2006), company size assessment can use the measure of total assets. In this study, researchers used a proxy for total assets, this was intended to reduce excess data fluctuations. If the total asset value is directly used, the variable value will be very large, billions or even trillions. Since the company's total assets are of large value, this can be simplified by transforming it into a natural logarithm, without changing the proportion of the original original value. The results of this study indicate that "company size has a negative and insignificant effect on firm value" which is in line with research from(Cecilia \& Bahri Torong, 2015) which states that company size has a negative and insignificant effect on firm value.

The probability value of liquidity $(\mathrm{X} 2)$ on firm value is $0.7374>0.05$, this means that liquidity is not significant to firm value. If the Cash Ratio is higher, the Firm Value will decrease. (Prastowo, 2011) states that the liquidity ratio serves to measure a company's ability to meet its short-term obligations. The liquidity of a company is able to describe the company's ability to meet its short-term obligations to short-term creditors, the greater the ratio of cash to debt, the better. The liquidity ratio that describes the company's financial performance in terms of liabilities can affect the public's assessment, especially investors, in order to give confidence to companies to invest. If the company still has a good ability to fulfill its short-term obligations (one year period) using current assets, the company can be said to be liquid, so investors don't have to worry about investing their funds, if something goes wrong. The results of this study indicate that liquidity has a positive and insignificant effect on firm value which is in accordance with the results of research conducted by (Mahendra, Sri Artini, \& Suarjaya, 2012).

The probability value of profitability (X3) on firm value is $0.6479(>0.05)$, this means that profitability is not significant to firm value. If the Return on Assets is higher, it will decrease the value of the company. Profitability ratio is a ratio used to measure the effectiveness of management as a whole which is aimed at the size of the level of profits obtained in relation to sales and investment. The profitability of a company, which is proxied by ROA, illustrates the company's ability to use its assets to make a profit (Prastowo, 2011). The results of this study indicate that there is a negative and insignificant influence on the ratio of profitability to firm value so that it supports the results of research conducted by (Thaib, 2017). The main goal of a company is to increase company value. The company's value will be guaranteed to grow in a sustainable manner if the company is able to improve its financial performance. If the financial performance of a company is described as high ROA, then the company value will also increase, because the company value is determined by the earnings power of the company's assets.

The solvency probability value $(\mathrm{X} 4)$ on firm value is $0.0000(<0.05)$ this means that the solvency is significant to firm value. If the Debt Ratio is higher, the Company Value will be better. Debt ratio is one of the solvency ratios that shows the company's ability to fulfill its obligations for both the short and long term. According to (Sawir, 2008) If the debt ratio is higher, while the proportion of total assets does not change, the debt owned by the company will get bigger. The larger the total debt, the higher the financial ratio or the company's failure to repay the loan. And conversely, if the debt ratio is getting smaller, the debt owned by the company will also be smaller and this means that the company's financial risk of repaying the loan is also getting smaller. The results show that the Debt Ratio has a positive and significant effect on Firm Value which supports the results of research conducted by (Susilaningrum , 2016). Firm value is a reflection of the market price of the company's shares formed between the seller and the buyer when the transaction occurs. The company value that is formed through the stock market value is influenced by the investment opportunities 
being considered by potential investors. A good solvency ratio will affect public confidence in a company, thereby increasing the value of the company. The solvency ratio is also an indicator to determine investment opportunities by potential investors. The results of this study indicate that solvency has a positive and significant effect on firm value, so that if the company has a high solvency ratio, the better company value in manufacturing companies with the automotive industry sub-sector listed on the Indonesia Stock Exchange for the 2015-2019 period.

The resulting regression equation is as follows.

$\mathrm{Y}=-0.017479 \mathrm{X} 1+0.026540 \mathrm{X} 2-0.638836 \mathrm{X} 3+3.114902-0.196095$

The calculated $\mathrm{F}$ value is 25.07886 with a probability of 0.000000 . Because the probability is much smaller than 0.05 , it can be concluded that the regression coefficient of firm size, liquidity, profitability and solvency is not equal to zero, or in other words $\mathrm{H} 1$ is accepted and rejects H0. The conclusion of the output is that four independent variables together have a significant effect on firm value. Thus H5 in this study is proven. According to (Mahendra, Sri Artini, \& Suarjaya, 2012) firm value is an important concept for investors, because it is an indicator for the market in assessing the company as a whole. Firm value can be influenced by factors, namely financial performance which includes solvency ratios, profitability and liquidity. In terms of financial performance, if a company maximizes financial performance, it is expected that the company's value can increase. The results of this study indicate that the ratio of solvency, profitability and liquidity simultaneously has a significant effect on firm value, which is in accordance with the results of previous research conducted by (Dasuha, 2017). Companies that have high profitability tend to have high company value as well. Firm value is mostly determined by ROA. Companies that have low liquidity ratios are ultimately unable to pay off short-term obligations that have fallen, thus affecting the company's long-term relationships with distributors, creditors and consumers. Economic conditions are not always stable, company risks certainly exist, but if bad things happen, the company will be liquidated (dissolved). It is necessary to consider the anticipation of the impact of liquidation, namely by taking into account the company's ability to pay off short-term and long-term liabilities through solvency ratio analysis. The solvency ratio shows the risk factors faced by investors, every investor expects a high rate of return and does not want the risk of their investment, so that if the solvency ratio increases, the number of investors as indicated by the number of shares outstanding in the market will also increase. The development of company value depends on the performance of company management, in this study it can be seen from the analysis of the company's financial ratios, including solvency ratio as measured by debt ratio, profitability ratio as measured by ROA, and liquidity ratio as proxied by cash ratio. This study also shows that financial performance has a significant effect on firm value.

The amount of the adjusted R2 is 0.690329 , this means that only $69.03 \%$ of the firm value variable is explained by the variables of company size, liquidity, profitability and solvency, while the remaining $30.97 \%$ is explained by other causes outside the model in this study.

\section{Conclusions}

Firm size has no effect on firm value. To achieve economies of scale a certain company size is required. However, due to the variation in the company's business subsector, the implications for achieving these economies of scale are different sizes. In a certain asset value, a business subsector has reached economies of scale, but not necessarily with other subsectors. Liquidity has no effect on firm value. Liquidity can bring a good image of the company but also has an impact on the inefficiency of current assets due to idle funds. Both of these have positive but also negative implications so that the end result liquidity has no effect on stock prices. Profitability has no effect on firm value. ROA contains elements of operating net income that do not consider interest expense and preferred stock dividends, while stock investors have an interest in income available to common stockholders who have deducted interest expense and preferred stock dividends from operating net income. Solvency has a positive effect on stock prices. The use of high debt decreases the number of shares so as to increase the dividend per share. Stock investors view that high dividends are a reflection of good company performance, which encourages an increase in stock prices.

The limitation of this study is that it only analyzes one sector, namely automotive and the observation period is only 5 years, the factors studied in influencing firm value are only on four variables, namely Company Size, Liquidity, Profitability and Solvency.

For this reason, further research is expected to use more research samples apart from automotive companies, for example, companies in the metal, textile, chemical, food, cigarette or cosmetics sub-sector listed on the Indonesia Stock Exchange (IDX), extend the research period and increase the number. the sample used, so that a better picture will be obtained about the value of the automotive sub-sector company in the Indonesia Stock Exchange. For academics, it is hoped that the results of this study can be used as a reference for research on Financial Accounting courses, especially in terms of analyzing company value. Based on the research results, it is known that simultaneously there is a significant influence on Firm Size, Liquidity, Profitability, and Solvency on Firm Value. Therefore, it is advisable for investors to consider the factors of company size, cash ratio, ROA and debt ratio, to company value, so that in the future investors can get profits, increase corporate value, and maintain public trust. 


\section{References}

Cecilia, R., \& Bahri Torong, M. Z. (2015). Analisis Pengaruh Corporate Social Responsibility, Profitabilitas dan Ukuran Perusahaan Terhadap Nilai Perusahaan pada Perusahaan Perkebunan yang Go Public di Indonesia, Malaysia, dan Singapura. Simposium Nasional Akuntansi, (pp. 1-22). Medan.

Dasuha, B. L. (2017). Pengaruh Current Ratio, Profitabilitas, Solvabilitas , dan Ukuran Perusahaan terhadap Nilai Perusahaan pada perusahaan manufaktur. Retrieved from http://repositori.usu.ac.id/handle/123456789/911

Deegan, R. (2002). The Legitimasing Effect of Social and Environment Disclosure -A Theoritical Foundation. Acoounting, Auditing and Accountability Journal, 10(4), 562-584.

Firnanda, T., \& Oetomo, H. W. (2016, Februari ). Analisis Likuiditas, Profitabilitas, Solvabilitas, dan Perputaran Persediaan Terhadap Nilai Perusahaan. Jurnal Ilmu dan Riset Manajemen, 5(2).

Ghozali, I. (2006). Aplikasi Analisis Multivariate dengan Program SPSS. Semarang: Universitas Diponegoro.

Hadi, N. (2011). Corporate Social Responsibility. Yogyakarta: Graha Ilmu.

Harmono. (2017). Manajemen Keuangan Berbasis Blanced. Jakarta: Bumi Angkasa Raya.

Haryono, S. A., Fitriany, \& Fatima, E. (2017, Desember). Pengaruh Struktur Modal dan Struktur Kepemilikan Terhadap Kinerja Perusahaan. Jurnal Akuntansi dan Keuangan Indonesia, 14(2), 119-141.

Hemastuti, C. (2014). Pengaruh Profitabilitas, Kebijakan Dividen, Kebijakan Hutang, Keputusan Investasi, dan KepemilikanInside Terhadap Nilai Perusahaan. Jurnal Ilmu \& Riset Akuntansi, 3(4).

Herawaty, A., \& Suwito, A. (2005). Analisis Pengaruh Karakteristik Perusahaan Terhadap Tindakan Perataan Laba yang Dilakukan Oleh Perusahaan yang Terdaftar di Bursa Efek Jakarta. (pp. 136-146). Solo: SNA VIII Solo.

Hermuningsih, S. (2013). Pengaruh Profitabilitas, Growth Opportunity, Sruktur Modal Terhadap Nilai Perusahaan Pada Perusahaan Publik Di Indonesia. Retrieved from https://doi.org/10.21098/bemp.v16i2.27

Jensen, M. C., \& Meckling, W. H. (1976). Theory of the Firm : Managerial Behavioral Agency Cost, and Ownership Structure. Journal of Finance Economics , 3(4), 305 - 306.

Jogiyanto, H. (2008). Teori Portofolio dan Analisis Investasi . Edisi Kelima. Yogyakarta: BPFE.

Jumingan. (2006). Analisis Laporan Keuangan. Jakarta: PT Bumi Aksara.

Kemenperin. (2018, Oktober Senin). Industri Otomotif Semakin Kencang Dobrak Pasar Ekspor. p. 1.

Mahendra, D. A., Sri Artini, L. G., \& Suarjaya, A. G. (2012, Agustus). Pengaruh Kinerja Keuangan Terhadap Nilai Perusahaan, pada Perusahaan Manufaktur Di. Jurnal Manajemen, Strategi Bisnis, dan Kewirausahaan, 6(2), 130-138.

Nurhayati, M. (2006). Profitabilitas, Likuiditas, dan Ukuran Perusahaan Pengaruhnya Terhadap Kebijakan Deviden Dan Nilai Perusahaan Sektor Non Jasa. Jurnal Keuangan dan Bisnis.

Pantow, M. S., Murni, S., \& Trang, I. (2015, Maret). Analisa Pertumbuhan Penjualan, Ukuran Perusahaan, Return On Asset, dan Struktur Modal Terhadap Nilai Perusahaan yang Tercatat Di Indeks LQ 45. Jurnal EMBA, 3(1), 961-971.

Permanasari, W. I. (2010). Pengaruh Kepemilikan Manajemen, Kepemilikan Institusional,dan Corporate Social Responsibility Terhadap Nilai Perusahaan. Retrieved from Universitas Diponegoro: http://www.enprints.undip.ac.id.

Prasetyorini, B. F. (2013). Pengaruh Ukuran Perusahaan, Leverage, Price Earning Ratio dan Profitabilitas terhadap Nilai Perusahaan. Jurnal Ilmu Manajemen, 1(1), 183-196.

Prastowo, D. (2011). Analisis Laporan Keuangan. In Ketiga (Ed.). Jakarta: YKPN.

Rahardjo, B. (2009). Laporan Keuangan Perusahaan: Membaca, Memahami, dan Menganalisis. In Dasar-dasar Analisis Fundamental Saham. Penerbit Gajah Mada University Press.

Ross, S. (1977). The Determination of Finacial Structure:The Incentive Signalling Approach. Journal of Economics, 8, $23-40$.

Saputri Dewi, P. Y., Yuniarta, G. A., Atmadja, T., \& Wikrama, A. (2014). Pengaruh Struktur Modal, Pertumbuhan Perusahaan dan Profitabilitas Terhadap Nilai Perusahaan Pada Perusahaan LQ 45 Di BEI Periode 2008-2012. e-Journal S1 Ak Universitas Pendidikan Ganesha, 2(1).

Solikin, I., Widaningsih , M., \& Lestari , S. D. (2015). Pengaruh Struktur Kepemilikan, Struktur Modal, Dan Ukuran Perusahaan Terhadap Nilai Perusahaan Pada Perusahaan Sektor Pertambangan Yang Terdaftar Di Bursa Efek Indonesia Tahun 20102012. Jurnal Riset Akuntansi dan Keuangan, 3(2), 724-740.

Susilaningrum, C. (2016 ). Pengaruh Return On Asset, Rasio Likuiditas dan Rasio Solvabilitas Terhadap Nilai Perusahaan dengan Pengungkapan Corporate Social Responsibility (CSR) sebagai Variabel Moderasi. Jurnal Profita Edisi 8, 1-17.

Publisher's Note: SSBFNET stays neutral with regard to jurisdictional claims in published maps and institutional affiliations.

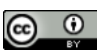

(C) 2021 by the authors. Licensee SSBFNET, Istanbul, Turkey. This article is an open access article distributed under the terms and conditions of the Creative Commons Attribution (CC BY) license (http://creativecommons.org/licenses/by/4.0/).

International Journal of Research in Business and Social Science (2147-4478) by SSBFNET is licensed under a Creative Commons Attribution 4.0 International License. 